American Journal of Immunology 5(3): 61-64, 2009

ISSN 1553-619X

(C) 2009 Science Publications

\title{
Hyper-Ag-specific Ab Production in NC/Nga Mice is not associated with Deletion Polymorphism in the Promotor Region of the FcyRIIB Gene
}

\author{
Tohru Sakai, Mariko Nakamoto and Emi Suto \\ Department of Public Health and Applied Nutrition, Institution of Health Bioscience, \\ University of Tokushima Graduate School, Tokushima, Tokushima 770-8503, Japan
}

\begin{abstract}
Problem statement: NC/Nga (NC) mice produced high levels of ovalbumin (OVA)specific IgG, IgG1 and IgG2a. We previously found deletion polymorphisms in the promoter region of fcgr $2 b$ in NC mice. To determine whether this mutation causes a hyper-humoral immune response, we generated congenic BALB/c mice carrying the NC-type fcgr $2 b$ allele (NC fcgr $2 b$ ) and analyzed humoral immune response and Fc $\gamma$ RIIB on germinal center (GC) B cells. Approach: BALB/c, NC and $\mathrm{BALB} / \mathrm{c}-\mathrm{NC}$ fcgr2b congenic mice were immunized with OVA 2 times at a 2-week-interval. Levels of OVA-specific IgG, IgG1 and IgG2a in serum were determined by ELISA. Four-color (antiB220, anti-IgD, 2.4G2 and PNA) flow cytometry analysis was performed on splenocytes obtained from OVA-immunized mice and levels of Fc $\gamma \mathrm{RIIB}$ in GC (IgD-PNA $\left.{ }^{\text {high }}\right)$ and non-GC (IgD+PNA $\left.{ }^{\text {low }}\right)$ B cells were analyzed. Results: Although perturbed up-regulation of Fc $\gamma$ RIIB on GC B was observed in congenic mice, levels of OVA-specific Abs were comparable to those in BALB/c mice. Conclusion: NC fcgr $2 b$ affects the level of Fc $\gamma R$ IIB in GC B cells but that the reduced Fc $\gamma$ RIIB expression is not related to enhanced $\mathrm{Ag}$-specific $\mathrm{Ab}$ responses in $\mathrm{NC}$ mice.
\end{abstract}

Key words: NC/Nga mice, Fc $\gamma$ RIIB, antibody, congenic mice

\section{INTRODUCTION}

Fc $\gamma$ RIIB, a low-affinity FcR for IgG, acts as a negative feedback regulator by inhibiting $\mathrm{B}$ Cell Receptor (BCR)-mediated activation signal through an immunotyrosine-based inhibition motif when these two receptors are co-cross-linked by $\mathrm{Ags}$ and IgGcontaining immune complex ${ }^{[1-3]}$. NC/Nga (NC) mice have been shown to develop human atopic-like skin lesions with elevated serum IgE level when kept in conventional conditions ${ }^{[4,5]}$. In the course of investigating these mechanisms, we found that $\mathrm{NC}$ mice produced a higher level of $\mathrm{Ag}$-specifc IgG2a than did $\mathrm{BALB} / \mathrm{c}$ mice and that $\mathrm{NC}$ mice have three deletion sites in regulatory regions of the FcyRIIB gene, two in the promoter region and one in the third intron ${ }^{[6]}$. We investigated the role of the NC-type fcgr2b allele (NC $\mathrm{fcgr} 2 \mathrm{~b}$ ) in humoral immune response in (BALB/c $\mathrm{x}$ $\mathrm{NC}) \times \mathrm{BALB} / \mathrm{c}$ or $(\mathrm{BALB} / \mathrm{c} \times \mathrm{NC}) \times \mathrm{NC}$ backcross mice. Results of analysis showed that hyper Ag-specific IgG2a is not controlled by NC fcgr $2 b^{[6]}$. However, the role of $\mathrm{NC}$ fcgr $2 \mathrm{~b}$ in $\mathrm{Ab}$ response is not fully understood. Establishment of congenic mice for NC fcgr $2 b$ made it feasible to examine the in vivo effect of fcgr $2 \mathrm{~b}$ allele polymorphism. In this study, we examined the effect of $\mathrm{NC}$ fcgr $2 \mathrm{~b}$ on $\mathrm{Ag}$-specific Ab response in a congenic mouse strain.

\section{MATERIALS AND METHODS}

Mice: Specific pathogen-free female NC and BALB/c mice were purchased from SLC (Hamamatsu, Japan). Congenic BALB/c mice carrying NC fcgr $2 b$ were generated by backcrossing ten times $(\mathrm{BALB} / \mathrm{c} \times \mathrm{NC}) \mathrm{F} 1$ mice $\times \mathrm{BALB} / \mathrm{c}$ mice. Genotyping for NC fcgr $2 b$ was done using anti-Ly 17.2 mAb. Anti-Ly 17.2 mAb reacts with BALB/c-type FcyRIIB but not with that of NC. Backcross mice showing reduced levels of Ly 17.2 staining were judged as being positive for $\mathrm{NC}$ fcgr $2 \mathrm{~b}$.

Immunization and flow cytometric analysis: Mice were intraperitoneally immunized with $10 \mu \mathrm{g}$ of Ovalubumin (OVA) (Sigma Chemical Co., MO, USA) absorbed in $1 \mathrm{mg}$ of Aluminium Hydroxide Gel Adjuvant (HCI Biosector, Denmark) 2 times at a 2week interval. Serum OVA-specific Ab levels were measured by the standard method. Spleen cells from OVA-immunized mice were stained FITC-anti-IgD

Corresponding Author: Tohru Sakai, Department of Public Health and Applied Nutrition, Institution of Health Bioscience, University of Tokushima Graduate School, Tokushima, Tokushima 770-8503, Japan Tel: +81-88-633-7096 Fax: +81-88-633-9427 
$\mathrm{mAb}$, PE-anti-Fc $\gamma$ RIIB/FcgRII mAb (clone 2.4G2), $\mathrm{APC}-a n t i-B 220 \mathrm{mAb}$ and biotin-peanut lectin (aggutinin) (PNA), followed by PerCP-streptavidin. Stained cells were analyzed by FACSCalibur and CellQuest software (BD Biosciences, Mountain View, CA).

Statistical analysis: Statistical analysis was done by one-way ANOVA followed by Sheffe's multiple comparison test. Values in the text are means \pm SD. Differences were considered significant at $\mathrm{p}<0.05$.

\section{RESULTS AND DISCUSSION}

$\mathrm{NC}$ mice produced significantly higher levels of $\mathrm{Ag}$-specific IgG, IgG1 and IgG2a Ab than did BLAB/c mice when immunized with OVA. Quantitative analysis using serially diluted serum revealed that the amounts of Ag-specific IgG2a Ab in NC/Nga mice were - 100times greater than those in BALB/c mice (data not shown). In congenic mice carrying $\mathrm{NC}$ fcgr $2 \mathrm{~b}$, levels of OVA-specific Ab response were comparable to those in BALB/c mice (Fig. 1). These results indicate that NC fcgr $2 b$ does not cause hyper $\operatorname{IgG}$ production and that genetic factors other than $\mathrm{NC}$ fcgr $2 \mathrm{~b}$ contribute to the hyper Ag-specific Ab response in NC mice.

The Germinal Center (GC) is a microenvironment formed in the follicles of secondary lymphoid organs by highly proliferative $\mathrm{B}$ cells responding to $\mathrm{T}$ celldependent Ags. It has been shown that Fc $\gamma$ RIIB on GC B cell regulates Ab-Forming Cells $(\mathrm{AFC})^{[7,8]}$. BCR and Fc $\gamma$ RIIB are cross-linked when GC B cells interact with $\mathrm{Ag}$, resulting in inhibition of AFC differentiation ${ }^{[9]}$. We evaluated the expression of Fc $\gamma$ RIIB in GC B cells because down-regulation of Fc $\gamma$ RIIB in the GC has been reported in NZB mice, which have deletion mutation of fcg2b similar to that in $\mathrm{NC}$ mice ${ }^{[10-12]}$. Figure 2 shows Fc $\gamma$ RIIB expression levels in GC (PNA $\left.{ }^{\text {high }} \mathrm{IgD}^{-}\right)$and non-GC $\left(\mathrm{PNA}^{\text {low }} \mathrm{IgD}^{+}\right)$B cells in $\mathrm{BALB} / \mathrm{c}$ and congenic mice at the time of primary immune response by OVA immunization. Expression of FcyRIIB was upregulated in GC B cells compared to that in non-GC B cells in BALB/c mice, whereas expression of FcyRIIB in congenic mouse GC B cells was two-fold lower than that in $\mathrm{BALB} / \mathrm{c}$ mice. Therefore, $\mathrm{NC}$ fcgr $2 \mathrm{~b}$ affects the level of FcyRIIB expression in GC B cells but does not affect Ag-specific Ab levels. Previous studies showed that expression of Fc $\gamma$ RIIB in GC B cells is down-regulated in NZB mice ${ }^{[11,12]}$. However, a recent study by Rahman showed that expression of Fc $\gamma$ RIIB in GC B cells is unchanged in autoimmuneprone mice by using multiple GC B cell maker $\mathrm{Ags}^{[13]}$. Our results showing increased expression of FcyRIIB in GC B cells are consistent with Rahman's report.

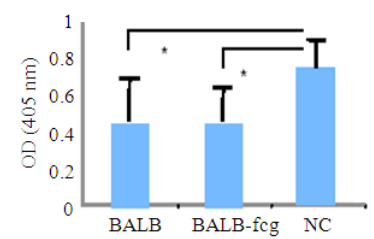

(a)

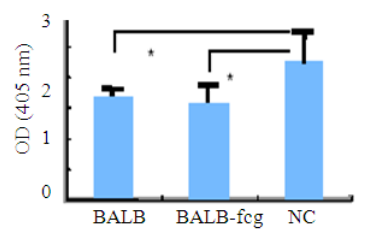

(b)

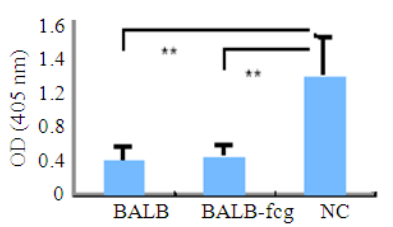

(c)

Fig. 1: OVA-specific $\mathrm{Ab}$ responses in $\mathrm{BALB} / \mathrm{c}$, $\mathrm{NC} / \mathrm{Nga}$ and $\mathrm{NC}$ fcgr $2 \mathrm{~b}$ congenic $\mathrm{BALB} / \mathrm{c}$ mice. Mice were immunized with OVA 2 times at a 2 week-interval. Levels of OVA-specific IgG; (a): IgG;1 (b): and IgG2a; (c): In serum were determined by ELISA. Data are presented as means \pm SD. $* \mathrm{p}<0.05 . * * \mathrm{p}<0.01^{[6]}$
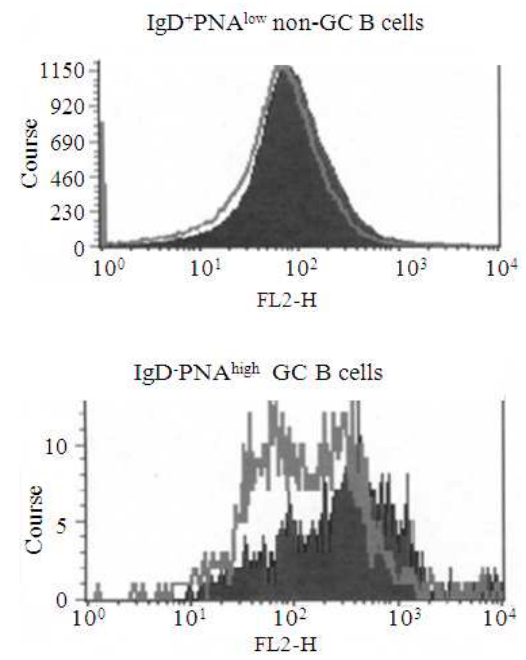

Fig. 2: Levels of Fc $\gamma$ RIIB in $\mathrm{GC}\left(\mathrm{IgD}^{-} \mathrm{PNA}^{\text {high }}\right)$ and non-GC $\left(\operatorname{IgD}^{+} \mathrm{PNA}^{\text {low }}\right) \mathrm{B}$ cells in $\mathrm{BALB} / \mathrm{c}$ and $\mathrm{NC}$ fcgr $2 \mathrm{~b}$ congenic BALB/c mice. Four-color (anti-B220, anti-IgD, 2.4G2 and PNA) flow cytometry analysis was performed on splenocytes obtained from OVA-immunized each mice on day 10 of primary immune response. Closed histograms indicate the profile for BALB/c mice. Open histograms indicate the profile for $\mathrm{NC}$ fcgr $2 \mathrm{~b}$ congenic BALB/c mice. The data are representative of two independent experiments of pooled samples from two to three mice ${ }^{[6]}$ 
Xiu examined the effect of NZB-type deletion polymorphism on transcriptional regulation of the fcgr $2 b$ gene and showed defective transcription activity in an NZB-derived segment due to absence of transcription by AP4, which binds to the polymorphic 13-nucleotide deletion site ${ }^{[12]}$. Since NC fcgr2b has the same mutation, this mutation might affect induction of Fc $\gamma$ RIIB level. The finding that $\mathrm{NC}$ fcgr $2 \mathrm{~b}$ does not induce hyper $\mathrm{Ab}$ production is unexpected because NZB-type fcgr $2 b$ congenic B6 mice show a stronger anti-KLH Ab response than do B6 mice ${ }^{[12]}$. Polymorphisms in putative regulatory regions of the Fc $\gamma$ RIIB gene in NZB and NC mice are identical. There are several possible reasons for the different results. First, genetic background might influence the effect of $\mathrm{NC}$ fcgr $2 \mathrm{~b}$ on $\mathrm{Ab}$ response since $\mathrm{BALB} / \mathrm{c}$ mice are known to be a mouse strain that induce $\mathrm{Th} 2$ response and show strong $\mathrm{Ab}$ response compare to $\mathrm{B} 6$ mice ${ }^{[14,15]}$. Fc $\gamma$ RIIB-deficient mice develop autoantibodies and glomerulonephritis with a pathology resembling that of human lupus on B6 background. The same mutation on the BALB/c background does not lead to spontaneous disease, suggesting that the effect of Fc $\gamma$ RIIB on susceptibility to the disease is different in BALB/c and B6 strains ${ }^{[16]}$. Several candidate genes for regulating autoantibody production proximal to fcgr $2 b$ have been reported $^{[17-19]}$. Thereby, contribution of these genes on Ag-specific Ab production is not excluded at present stage.

\section{CONCLUSION}

The present study showed that $\mathrm{NC}$ fcgr $2 \mathrm{~b}$ affects the level of Fc $\gamma$ RIIB in GC B cells but that the reduced Fc $\gamma$ RIIB expression is not related to enhanced Agspecific $\mathrm{Ab}$ responses in $\mathrm{NC}$ mice. In addition, the results showed the contribution of the deletion mutation in the promoter region of fcgr $2 b$ to the humoral immune response might be limited.

\section{REFERENCES}

1. Amigorena, S., C. Bonnerot, J.R. Drake, D. Choquet and W. Hunziker et al., 1992. Cytoplasmic domain heterogeneity and functions of $\mathrm{IgG}$ Fc receptors in B lymphocytes. Science, 256: 1808-1812. http://cat.inist.fr/?aModele $=$ afficheN\&cpsidt $=5433$ 478

2. Bolland, S. and J.V. Revetch, 1999. Inhibitory pathways triggered by ITIM-containg receptors. Adv. Immunol., 72: 149-177. http://www.ncbi.nlm.nih.gov/pubmed/10361574
3. Takai, T., 2002. Roles of Fc receptors in autoimmunity. Nat. Rev. Immunol., 2: 580-592. http://www.ncbi.nlm.nih.gov/pubmed/12154377

4. Matsuda, H., N. Watanabe, G.P. Geba, J. Sperl and M. Tsudzuki et al., 1997. Development of atopic dermatitis-like skin lesion with hyperproduction in NC/Nga mice. Int. Immunol., 9: 461-466. http://www.ncbi.nlm.nih.gov/pubmed/9088984

5. Matsumoto, M., C. Ra, K. Kawamoto, H. Sato and A. Itakura et al., 1999. IgE hyperproduction through enhanced tyrosine phosphorylation of Janus kinase 3 in NC/Nga mice, a model for human atopic dermatitis. J. Immunol., 162: 1056-1063. http://cat.inist.fr/?aModele=afficheN\&cpsidt=9913321

6. Sakai, T., M. Kogiso, K. Mitsuya, T. Komatsu and S. Yamamoto, 2006. Deletion polymorphisms in the promotor region of Fcg receptor IIB is not associated with antigen-specific IgG2a and $\operatorname{IgG} 2 \mathrm{~b}$ antibody responses in NC/Nga Mice. Microbiol. Immunol., 50: 475-480. http://cat.inist.fr/?aModele $=$ afficheN\&cpsidt $=17952925$

7. Berek, C., A. Berger and M. Apel, 1991. Maturation of the immune response in germinal centers. Cell, 90: 293-301. http://www.ncbi.nlm.nih.gov/pubmed/1760840

8. Jacob, J., G. Kelsoe, K. Rajewsky and U. Weiss, 1991. Intraclonal generation of antibody mutants in germinal centers. Nature, 354: 389-392. http://cat.inist.fr/?aModele=afficheN\&cpsidt=5174446

9. Tarlinton, D.M. and K.G. Smith, 2000. Dissecting affinity maturation: A model explaining selection of antibody-forming cells and memory B cells in the germinal center. Immunol. Today, 21: 436-441. http://www.ncbi.nlm.nih.gov/pubmed/11738998

10. Luan, J.J., R.C. Monteiro, C. Sautes, G. Fluteau and L. Eloy et al., 1996. Defective FcyRII gene expression in macrophages of NOD mice. J. Immunol., $\quad$ 157: 4707-4716. http://www.jimmunol.org/cgi/content/abstract/157/ 10/4707

11. Jiang, Y., S. Hirose, M. Abe, R. Sanokawa-Akakura and M. Ohtsuji et al., 2000. Polymorphisms in IgG Fc receptor IIB regulatory regions associated with autoimmune susceptibility. Immunogenetics, 51: 429-435. http://www.ncbi.nlm.nih.gov/pubmed/10866109

12. Xiu, Y., K. Nakamura, M. Abe, N. Li and X.S. Wen et al., 2002. Transcriptional regulation of Fcgr $2 b$ by polymorphic promoter region and its contribution to humoral immune responses. $\mathrm{J}$. Immunol., $\quad$ 169: 4340-4346. http://www.ncbi.nlm.nih.gov/pubmed/12370366 
13. Rahman, Z.S.M. and T. Manser, 2005. Failed upregulation of the inhibitory $\operatorname{IgG} \mathrm{Fc}$ receptor Fc $\gamma$ RIIB on germinal center $B$ cells in autoimmune-prone mice is not associated with deletion polymorphisms in the promoter region of the FcrRIIB gene. J. Immunol., 175: 1440-1449. http://www.ncbi.nlm.nih.gov/pubmed/16034080

14. Reiner, S.L. and R.M. Locksley, 1995. The regulation of immunity to Leishmania major. Annu. Rev. Immunol., 12: 151-177. http://www.ncbi.nlm.nih.gov/pubmed/7612219

15. Sher, A. and R.L. Coffman, 1992. Regulation of immunity to parasites by $\mathrm{T}$ cells and $\mathrm{T}$ cell-derived cytokines. Annu. Rev. Immunol., 10: 385-409. http://www.ncbi.nlm.nih.gov/pubmed/1590992

16. Terasenko, T., H.K. Kole and S. Bolland, 2008. A lupus-suppressor $\mathrm{BALB} / \mathrm{c}$ locus restricts $\mathrm{IgG} 2$ autoantibodies without altering intrinsic B celltolerance mechanisms. J. Immunol., 180: 3807-3814. http://www.ncbi.nlm.nih.gov/pubmed/18322187
17. Boackle, S.A., V.M. Holers, X. Chen, G. Szakonyi, D.R. Karp, E.K. Wakeland and L. Morel, 2001. $\mathrm{Cr} 2$, a candidate gene in the murine Sle1c lupus susceptibility locus, encodes a dysfunctional protein. Immunity, 15: 775-785. http://cat.inist.fr/?aModele $=$ afficheN\&cpsidt $=1338$ 0515

18. Morel, L., K.R. Blenman, B.P. Croker and E.K. Wakeland, 2001. The major murine systemic lupus erythematosus susceptibility locus, Sle1, is a cluster of functionally related gene. Proc. Natl. Acad. Sci. USA., 98: 1787-1792. http://adsabs.harvard.edu/abs/2001PNAS...98.1787 $\mathrm{M}$

19. Rozzo, S., J.J.D. Allard, D. Choubey, T.J. Vyse, S. Izui, G. Peltz and B.L. Kotzin, 2001. Evidence for an interferon-inducible gene, ifi202, in the susceptibility to systemic lupus erythematosus. Immunity, 15: 435-443. http://www.ncbi.nlm.nih.gov/pubmed/11567633 